\title{
Kompetensi Lulusan Mahasiswa Akuntansi Menghadapi Era Industri 4.0
}

\author{
Mega Mayasari ${ }^{\mathrm{a}}$, Anjelina $^{\mathrm{b}^{*}}$ and Irsutamic \\ a Jurusan Manajemen Bisnis, Politeknik Negeri Batam,mega@polibatam.ac.id, Indonesia \\ burusan Manajemen Bisnis, PoliteknikNegeriBatam,anjelina@polibatam.ac.id, Indonesia \\ 'Jurusan Manajemen Bisnis, Politeknik Negeri Batam, tami@polibatam.ac.id, Indonesia
}

\begin{abstract}
Abstrak. Penelitian ini bertujuan untuk mengetahui apakah sertifikasi kompetensi yang selama ini diperoleh mahasiswa di jenjang perkuliahan akan digunakan di dunia kerja/industri. Penelitian ini juga ingin mengetahui persepsi industri terkait dengan skill mahasiswa Akuntansi Politeknik Negeri Batam yang telah bekerja di industri, dan mengetahui skill yang diperlukan lulusan mahasiswa Akuntansi agar dapat bersaing di Era Industri 4.0. Sampel dari penelitian ini adalah Bagian HRD/atasan langsung mahasiswa Prodi Akuntansi dan Prodi Akuntansi Manajerial Politeknik Negeri Batam yang telah magang atau bekerja. Penelitian ini merupakan penelitian deskriptif kuantitatif. Hasil dari penelitian ini menunjukkan bahwa Sertifikasi kompetensi yang selama ini diadakan oleh jurusan manajemen bisnis ternyata memang dibutuhkan di dunia kerja yaitu sertifikasi SAP, TUK, MYOB. Persepsi industri terkait dengan skill mahasiswa Akuntansi Politeknik Negeri Batam skill yang sudah dimiliki adalah pembelajaran yang aktif dan strategis, berpikir analitis dan inovatif, skill kemampuan analitis dan daya pikir kritis, skill kreativitas, originalitas dan inisiatif, skill kecerdasan emosional, kemampuan memecahkan masalah yang sulit dan skill logika penyelesaian masalah, reasoning dan penuh ide. kemampuan analisis sistem dan evaluasi. kepemimpinan dan kemampuan memberikan pengaruh kepada lingkungan sosial dan kemampuan programming dan teknologi desain. Skill yang diperlukan lulusan mahasiswa Akuntansi agar dapat bersaing di Era Industri 4.0 hasil perangkingan industri adalah skill pembelajaran yang aktif dan strategis skill berpikir analitis dan inovatif, skill kreativitas, originalitas, dan inisiatif, skill kemampuan programming dan teknologi desain, skill kecerdasan emosional, skill logika penyelesaian masalah, reasoning, dan penuh ide, skill kepemimpinan dan kemampuan memberikan pengaruh kepada lingkungan sosial, skill kemampuan memecahkan masalah yang sulit, skill kemampuan analisis sistem dan evaluasi dan skill kemampuan analitis dan daya pikir kritis.
\end{abstract}

Kata Kunci: Era Industri 4.0, mahasiswa Akuntansi, sertifikasi kompetensi

${ }^{*}$ Corresponding author. E-mail: anjelina@polibatam.ac.id 


\section{Pendahuluan}

Lulusan sebuah perguruan tinggi pendidikan kejuruan (vokasi) tidak cukup hanya berbekal ijazah saja. Lulusan harus dibekali dengan kompetensi sebagai pendamping ijazah. Saat ini sarjana harus memiliki sertifikasi kompetensi untuk dapat menjadi pekerja professional yang dibutuhkan di era revolusi indusri 4.0. Sertifikat kompetensi ini dapat dijadikan salah satu lampiran Surat Keterangan Pendamping Ijazah (SKPI) yang juga akan berguna bagi lulusan saat melamar pekerjaan nantinya ${ }^{1}$. Hal ini didukung oleh Peraturan Pemerintah Nomor 4 tahun 2014 tentang penyelenggaraan pendidikan tinggi dan pengelolaan perguruan tinggi pasal 19 yang menyatakan bahwa sertifikat profesi diterbitkan oleh perguruan tinggi bersama dengan Kementerian, Kementerian Lain, LPNK, dan/atau Organisasi Profesi. Inti dari peraturan tersebut adalah mengharuskan perguruan tinggi untuk membekali sertifikat kompetensi bagi lulusannya.

Jurusan Manajemen Bisnis Politeknik Negeri Batam adalah jurusan yang terdiri dari tiga program studi yaitu Program Studi Akuntansi, Program Studi Akuntansi Manajerial dan Program Studi Administrasi Bisnis Terapan. Penelitian ini hanya berfokus kepada sertifikat lulusan Program Studi Akuntansi dan Akuntansi Manajerial, karena tujuan dari penelitian ini hanya melihat kompetensi yang dibutuhkan oleh mahasiswa Akuntansi. Setiap tahun Prodi Akuntansi dan Akuntansi Manajerial melakukan ujian sertifikasi kompetensi bagi lulusannya. Sertifikasi yang biasa dilakukan adalah sertifikasi TUK Teknisi Akuntansi, sertifikasi MYOB dan Sertifikasi SAP. Sertifikasi kompetensi bertujuan untuk memastikan dan memelihara kompetensi yang dimiliki oleh lulusan, sebagai wujud pengakuan yang dapat meningkatkan kredibilitas sebuah profesi dan meyakinkan perusahaan bahwa dirinya (tenaga kerja) kompeten di bidangnya ${ }^{2}$.

Melihat pentingnya sertifikasi kompetensi tersebut maka tujuan dari penelitian ini untuk menelaah lebih lanjut apakah sertifikasi kompetensi yang selama ini sudah diadakan di Jurusan Manajemen Bisnis, benarbenar dibutuhkan dan akan dipakai di dunia kerja

\footnotetext{
${ }^{1}$ Dapat diakses di:

https://radarsurabaya.jawapos.com/read/2019/01/30/116809/samb ut-revolusi-industri-40-gubernur-dorong-pendidikan-vokasi

Dapat diakses di

http://wartakota.tribunnews.com/2018/11/15/sertifikasikompetensi-tingkatkan-kredibilitas-profesi-lulusan-fti-ubsi.
}

khususnya industri?. Saat ini kita telah memasuki Era industri 4.0, dimana dibutuhkan keselarasan antara perguruan tinggi dan industri. Di era tersebut, industri tidak hanya membutuhkan SDM yang unggul dan handal, tapi juga memiliki skill atau keahlian sesuai kebutuhan dunia industri ${ }^{3}$. Tantangan dan peluang industri 4.0 mendorong inovasi dan kreasi pendidikan kejuruan. Pemerintah perlu meninjau relevansi antara pendidikan kejuruan dan pekerjaan untuk merespon perubahan, tantangan, dan peluang era industri 4.0 dengan tetap memperhatikan aspek kemanusiaan (humanities) (Yahya, 2018).

Irianto (2017) dalam Yahya (2018) menyebutkan tantangan industri 4.0 yaitu; kesiapan industri, tenaga kerja terpercaya, kemudahan pengaturan sosial budaya, dan diversifikasi dan penciptaan lapangan kerja dan peluang industri 4.0 yaitu; inovasi ekosistem, basis industri yang kompetitif, investasi pada teknologi, dan integrasi Usaha Kecil Menengah (UKM) dan kewirausahaan. Hal ini sejalan dengan hasil survei dari World Economic Forum (WEF), Future of Jobs Survey (2018), yang menyebutkan terdapat 10 skill yang dibutuhkan tenaga kerja agar dapat bersaing pada masa datang. Sepuluh skill tersebut adalah (1) Berpikir analitis dan inovatif (2) Pembelajar yang aktif dan strategis (3) Kreativitas, originalitas, dan inisiatif (4) Kemampuan programming dan teknologi desain (5) Kemampuan analitis dan daya pikir kritis (6) Kemampuan memecahkan masalah yang sulit (7) Kepemimpinan dan kemampuan memberikan pengaruh kepada lingkungan sosial (8) Kecerdasan emosional (9) Logika penyelesaian masalah, reasoning, dan penuh ide (10) Kemampuan analisis sistem dan evaluasi. WEF menjelaskan, keterampilan-keterampilan yang akan semakin dibutuhkan adalah daya pikir analitis serta pembelajaran secara aktif sekaligus keterampilan yang berkaitan dengan teknologi lantaran kebutuhan atas teknologi yang terus meningkat ${ }^{4}$.

Penelitian berkaitan dengan lingkungan kerja pada industri 4.0 pernah diteliti oleh Kazancoglu dan Ozen (2017). Tujuan dari penelitian tersebut adalah pertama, untuk menyajikan model struktural untuk industri 4.0; kedua, untuk mengetahui kriteria pemilihan personil di lingkungan Industri 4.0; dan ketiga, untuk berkontribusi pada literatur manajemen

\footnotetext{
${ }^{3}$ Dapat diakses di:

https://radarsurabaya.jawapos.com/read/2019/01/30/116809/samb ut-revolusi-industri-40-gubernur-dorong-pendidikan-vokasi

${ }^{4}$ Dapat diakses:

https://ekonomi.kompas.com/read/2018/11/09/101201726/ditahun-2022-skill-apa-saja-yang-paling-dibutuhkan-untuk-bekerja
} 
operasi dengan berfokus pada proses rekrutmen di lingkungan Industri 4.0 dan mendukung kegiatan sumber daya manusia dengan kriteria terkait Industri 4.0 dan menunjukkan bidang penelitian baru di Industri 4.0. Hasil dari penelitian tersebut menunjukkan bahwa kriteria yang paling penting dalam perusahaan, yang dipilih adalah kemampuan untuk berurusan dengan kompleksitas dan penyelesaian masalah, berpikir dalam proses yang tumpang tindih, dan fleksibilitas untuk menyesuaikan peran dan lingkungan kerja baru. Selanjutnya kriteria yang mempengaruhi kelompok adalah pengetahuan tentang TI dan teknologi produksi, kesadaran akan keamanan TI dan perlindungan data, dan kemampuan pemulihan dari kesalahan berkaitan dengan data, fleksibilitas untuk menyesuaikan peran dan lingkungan kerja baru, pemahaman organisasi dan proses, dan kemampuan untuk berinteraksi dengan modern interface. Kazancoglu dan Ozen (2017) menekankan bahwa pemikiran analitis dan pendekatan sistem adalah topik utama untuk kriteria pemilihan personel pendukung baru, yang mengarah pada kebutuhan akan skill (keterampilan) dan kualifikasi dalam pengambilan keputusan dan manajemen proses.

Penelitian Majid, Eapen, Aung dan Oo (2019) meneliti tentang perlunya soft skill untuk mencari pekerjaan serta untuk karier yang produktif, sukses, dan memuaskan. Tujuan penelitian tersebut adalah untuk menyelidiki persepsi mahasiswa tentang pentingnya soft skill dan kepuasan mereka dengan tingkat keterampilan yang dimiliki oleh mereka. Selain itu, penelitian tersebut juga mengeksplorasi harapan dan kepuasan pengusaha terhadap tingkat soft skill yang dimiliki oleh lulusan. Penelitian tersebut menggunakan sampel 132 mahasiswa pascasarjana dari Nanyang Technological University, Singapura dan 16 pengusaha dari berbagai industry. Hasil penelitian tersebut menunjukkan bahwa mahasiswa menyadari pentingnya soft skill dalam kemampuan kerja dan pengembangan karir yaitu positive attitude, oral communication, self-motivation and self-direction, and problem solving. Di sisi lain, pengusaha berharap lulusan memiliki keterampilan yang terkait dengan positive attitude, teamwork, good ethics, and problem solving. Namun, pemberi kerja merasa bahwa lulusan yang baru bekerja bisaya memiliki soft skill yang kurang memuaskan. Hasil penelitian tersebut menyarankan mengajarkan soft skill kepada siswa, di mana keterampilan ini harus tertanam dalam kurikulum. Villiers (2010) meneliti bagaimana soft skill dapat melengkapi keterampilan teknis yang diajarkan untuk memastikan bahwa lulusan dibekali untuk menghadapi tuntutan lingkungan bisnis global yang kompleks. Hasil penelitian tersebut menunjukkan soft skill yang dibutuhkan oleh akuntan adalah communication skills, problem-solving and thinking skill, leadership and team work skills, ethical and moral values dan self-management

Perbedaan penelitian ini dengan penelitian terdahulu dalam hal. Pertama, penelitian ini merupakan penelitian deskriptif kuantitatif yang menggabungkan antara skill utama yang berkaitan dengan kompetensi mahasiswa akuntansi dalam mengikuti sertifikasi dan soft skill. Kedua penelitian ini melihat dari sudut pandang user/perusahaan yang mempekerjakan mahasiswa akuntansi atau melakukan perekrutan magang. Ketiga Skill yang dijadikan acuan dalam penelitian ini berdasarkan skill hasil survei dari Future of job report, Word Economic Forum (2018) menyebutkan bahwa terdapat sepuluh skill yang membuat tenaga kerja dapat bersaing dimasa datang. Tujuan dari penelitian ini adalah untuk mengetahui apakah sertifikasi kompetensi yang selama ini diadakan oleh jurusan manajemen bisnis digunakan dan terpakai di dunia kerja/industri. Kedua, untuk mengetahui persepsi industri terkait dengan skill yang dimiliki mahasiswa Akuntansi Politeknik Negeri Batam yang telah bekerja di industri. Ketiga, untuk mengetahui skill yang dibutuhkan untuk menjadikan lulusan perguruan tinggi bidang Akuntansi dapat bersaing di Era Industri 4.0. Hasil dari penelitian ini diharapkan dapat menjadi manfaat teoritis dari hasil penelitian ini diharapkan dapat memberikan kontribusi atau tambahan literatur teori berkaitan dengan kompetensi mahasiswa di Era Industri 4.0. Selain itu manfaat kebijakan dari hasil penelitian ini diharapkan dapat memberikan kontribusi kepada Jurusan Manajemen Bisnis Politeknik Negeri Batam dalam membekali mahasiswa sebelum kegiatan magang dilakukan.

\section{Tinjauan Pustaka}

\section{Sertifikasi Kompetensi}

Definisi sertifikasi lulusan mengacu pada Peraturan Menteri Pendidikan dan Kebudayaan Republik Indonesia Nomor 83 tahun 2013 tentang sertifikasi kompetensi, dalam Pasal 1, ayat (1) menyatakan bahwa Sertifikat kompetensi merupakan pengakuan kompetensi kerja atas prestasi lulusan yang sesuai dengan keahlian dalam cabang ilmunya dan/atau memiliki prestasi di luar program studinya. 
Pasal 1, ayat (2) menjelaskan bawa Sertifikat kompetensi diterbitkan oleh perguruan tinggi bekerja sama dengan organisasi profesi, lembaga pelatihan, atau lembaga sertifikasi yang terakreditasi. Pasal 1, ayat (3) Sertifikat kompetensi sebagaimana dimaksud pada ayat (2) diterbitkan oleh perguruan tinggi yang memiliki program studi yang sesuai dengan bidang ilmu dari kompetensi yang akan disertifikasi. Pasal 1, ayat (4) Uji kompetensi dilakukan oleh perguruan tinggi bekerja sama dengan organisasi profesi, lembaga pelatihan, atau lembaga sertifikasi.

\section{Era Industri 4.0}

Revolusi industri adalah pengenalan fasilitas produksi mekanik yang dimulai pada pertengahan abad ke-18 kemudian ditingkatkan selama abad ke19. Sejak tahun 1870-an, elektrifikasi dan taylorisme mengarah ke revolusi industri kedua. Selanjutnya revolusi industri ketiga, juga disebut "revolusi dgital" terjadi sekitar tahun 1970-an, ketika elektronik dan teknologi informasi mengembangkan otomatisasi proses produksi. Setelah revolusi industri ketiga, muncul inisiatif yang disebut "Industri 4.0", di mana perwakilan bisnis, politik dan akademisi berkumpul (Kagermann dkk., 2011), mempromosikan gagasan digitalisasi bersama dengan beberapa otonomi dan mesin sebagai pendekatan untuk memperkuat daya saing dari industri manufaktur Jerman. Industri 4.0 mendefinisikan suatu metodologi untuk menghasilkan transformasi dari proses manufaktur yang didominasi oleh mesin beralih ke digital manufaktur. Berikut rincian kemajuan industri dalam perspektif sejarah (Oztemel dan Gursev, 2018).

1. Industri 1.0 (Abad ke-18): Mekanikal produksi, menggunakan tenaga uap dan air.

2. Industri 2.0 (Abad ke-19): Jalur produksi masal membutuhkan tenaga kerja manusia dan energi listrik

3. Industri 3.0 (Abad ke-20): Produksi otomatis menggunakan elektonik dan teknologi informasi (TI)

4. Industri 4.0 (sekarang): Produksi cerdas yang tergabung dengan internet of things (IoT), teknologi cloud dan big data.

Menurut Kagermann, dkk (2013) industri 4.0 memiliki potensi yang besar, karena smart factories atau pabrik cerdas memungkinkan persyaratan pelanggan terpenuhi artinya barang tersebut dapat diproduksi dengan menguntungkan. Di industri 4.0, proses bisnis dan rekayasa yang dinamis memungkinkan perubahan pada menit-menit terakhir untuk produksi dan memberikan kemampuan untuk merespons secara fleksibel gangguan dan kegagalan, selain itu juga memberikan transparansi selama proses pembuatan dan memfasilitasi pengambilan keputusan yang optimal. Industri 4.0 juga akan menghasilkan cara-cara baru untuk menciptakan nilai dan model bisnis baru. Industri 4.0 dapat mengatasi dan memecahkan tantangan yang dihadapi dunia saat ini seperti efisiensi sumber daya dan energi dan perubahan demografis. Industri 4.0 memungkinkan peningkatan produktivitas sumber daya dan efesiensi yang berkelanjutan dikirimkan keseluruh jaringan nilai, sehingga memungkinkan pekerjaan diatur sedemukian rupa dngan memperhitungkan perubahan demografis dan faktor sosial. Industri 4.0 memberikan smart assistance system untuk membebaskan pekerja dari keharusan melakukan tugas-tugas rutin dan memungkinkan mereka untuk fokus pada kegiatan kreatif dan bernilai tambah. Pelaksanaan industri 4.0 akan berhasil jika disertai dengan kegiatan penelitian dan pengembangan $(R \& D)$ yang sesuai dengan industri tersebut. Kelompok kerja industri 4.0 memberikan 8 kunci tindakan yang diperlukan untuk industri 4.0:

1. Standarisasi dan arsitektur rujukan: Industri 4.0 akan melibatkan jaringan dan integrasi beberapa perusahaan yang berbeda melalui jaringan nilai. Kemitraan kolaboratif ini hanya akan terjadi jika satu set standar bersama dikembangkan. Arsitektur rujukan akan diperlukan untuk memberikan deskripsi teknis tentang standar-standar ini dan memfasilitasi implementasinya.

2. Pengelolaan system yang kompleks: Produk dan sistem manufaktur menjadi semakin kompleks. Model perencanaan dan penjelasan yang tepat dapat memberikan dasar untuk mengelola kompleksitas yang berkembang ini. Oleh karena itu, insinyur harus dilengkapi dengan metode dan alat yang diperlukan untuk mengembangkan model tersebut.

3. Infrastruktur broadband yang komprehensif: Jaringan komunikasi yang andal, komprehensif, dan berkualitas tinggi adalah persyaratan utama bagi Industri 4.0. Infrastruktur Internet Broadband perlu diperluas dalam skala besar, baik di negara industri tersebut maupun dengan negara-negara mitranya.

4. Keselamatan dan keamanan: Keduanya penting untuk keberhasilan sistem manufaktur yang 
cerdas. Penting untuk memastikan bahwa fasilitas produksi dan produk itu sendiri tidak menimbulkan bahaya baik bagi manusia maupun lingkungan. Pada saat yang sama, baik fasilitas produksi dan produk dan khususnya data dan informasi perlu dilindungi terhadap penyalahgunaan dan akses tidak sah. Ini akan membutuhkan, misalnya, penyebaran arsitektur keselamatan dan keamanan terpadu dan pengidentifikasi unik, bersama dengan perangkat tambahan yang relevan untuk pelatihan dan melanjutkan konten pengembangan profesional.

5. Organisasi kerja: di smart factories, peran karyawan akan berubah secara signifikan. Kontrol yang semakin real-time akan mengubah konten kerja, proses kerja, dan lingkungan kerja. Implementasi pendekatan sosial-teknis untuk organisasi kerja akan menawarkan kepada pekerja kesempatan untuk menikmati tanggung jawab yang lebih besar dan meningkatkan pengembangan pribadi mereka. Agar ini dimungkinkan, perlu untuk menerapkan desain kerja partisipatif dan langkah-langkah pembelajaran berkelanjutan dan untuk meluncurkan proyek referensi model.

6. Pelatihan dan pengembangan yang berkelanjutan: Industrie 4.0 secara radikal akan mengubah pekerjaan dan profil kompetensi pekerja. Karena itu akan diperlukan untuk menerapkan strategi pelatihan yang tepat dan untuk mengatur pekerjaan dengan cara yang mendorong pembelajaran berkelanjutan. Untuk mencapai ini, proyek model dan "best practice network" harus dipromosikan dan teknik pembelajaran digital harus diselidiki.

7. Regulatory framework: Sementara proses manufaktur baru harus mematuhi hukum, undang-undang yang ada juga perlu disesuaikan untuk memperhitungkan inovasi baru. Tantangannya termasuk perlindungan data perusahaan, masalah pertanggungjawaban, penanganan data pribadi dan pembatasan perdagangan. Hal ini akan membutuhkan tidak hanya undang-undang tetapi juga jenis tindakan lain atas nama bisnis - ada beragam instrumen yang sesuai, termasuk pedoman, kontrak model dan perjanjian perusahaan atau inisiatif pengaturan diri seperti audit.

8. Efisiensi sumber daya: Terlepas dari biaya yang tinggi, konsumsi bahan baku dan energi dalam jumlah besar di industri manufaktur juga menimbulkan sejumlah ancaman terhadap lingkungan dan keamanan pasokan. Industrie 4.0 akan memberikan keuntungan dalam produktivitas dan efisiensi sumber daya. Diperlukan perhitungan trade-off antara sumber daya tambahan yang perlu diinvestasikan di pabrik pintar dan potensi penghematan yang dihasilkan.

Tantangan dan peluang industri 4.0 mendorong inovasi dan kreasi pendidikan kejuruan. Pemerintah perlu meninjau relevansi antara pendidikan kejuruan dan pekerjaan untuk merespon perubahan, tantangan, dan peluang era industri 4.0 dengan tetap memperhatikan aspek kemanusiaan (humanities) (Yahya, 2018). Selain itu berdasarkan survei dari Future of job report, Word Economic Forum (2018) menyebutkan bahwa terdapat sepuluh skill yang membuat tenaga kerja dapat bersaing dimasa datang.

Irianto (2017) dalam Yahya (2018) menyederhanakan tantangan industri 4.0 yaitu; (1) kesiapan industri; (2) tenaga kerja terpercaya; (3) kemudahan pengaturan sosial budaya; dan (4) diversifikasi dan penciptaan lapangan kerja dan peluang industri 4.0 yaitu; (1) inovasi ekosistem; (2) basis industri yang kompetitif; (3) investasi pada teknologi; dan (4) integrasi Usaha Kecil Menengah (UKM) dan kewirausahaan.

\section{Metode Penelitian}

\section{Metode Analisis Data}

Penelitian ini merupakan penelitian deskriptif kuantitatif. Penelitian ini bertujuan menjelaskan dan menggambarkan karakteristik sesuatu. Penelitian ini mendeskripsikan sertifikasi kompetensi yang dipakai di industri dan persepsi industri terkait dengan skill mahasiswa akuntansi Politeknik Negeri Batam dan skill yang dibutuhkan oleh lulusan untuk menghadapi Era industri 4.0. Analisis data diarahkan pada pencarian data persentase.

\section{Instrumen Penelitian}

Instrumen penelitian ini adalah kuesioner. Kuesioner Penelitian diadaptasi dari Future of job report, Word Economic Forum (2018). Kuesioner penelitian ini terdiri dari dua bagian, bagian pertama adalah isi kuesioner dan bagian kedua adalah identitas responden. 


\section{Lokasi dan Obyek Penelitian}

Lokasi penelitian ini di Politeknik Negeri Batam dan objek penelitian adalah perusahaan yang karyawannya menempuh pendidikan kelas karyawan di Prodi Akuntansi dan Prodi Akuntansi Manajerial di Politeknik Negeri Batam yang berlokasi di Batam Centre. Perusahaan tempat mahasiswa prodi Akuntansi dan Akuntansi Manajerial Magang.

\section{Teknik Penarikan Sampel}

Penelitian ini menggunakan teknik penarikan sampel purposive sampling dengan kriteria sampel penelitian merupakan:

1. Bagian HRD/atasan langsung dari mahasiswa kelas karyawan Prodi Akuntansi dan Prodi Akuntansi Manajerial bekerja.

2. Bagian HRD/atasan langsung mahasiswa yang mengikuti FGD kurikulum akuntansi dan akuntansi manajerial

3. Bagian HRD/atasan langsung mahasiswa magang Politeknik Negeri Batam khususnya Prodi Akuntansi dan Prodi Akuntansi Manajerial.

Alasan pemilihan sampel Bagian HRD perusahaan karena penelitian ini dilakukan dengan melihat sudut pandang user/pengguna. Pengguna disini adalah Perusahaan yang mempekerjakan mahasiswa akuntansi atau yang telah merekrut mahasiswa dalam program magang. HRD tempat mahasiswa bekerja mewakili perusahaan tersebut. Karena bagian HRD yang akan memeberikan penilaian terkait kinerja mahasiswa yang bekerja dan mahasiswa magang. Berikut ini adalah rincian jumlah responden penelitian:

Tabel 1

Total data responden

\begin{tabular}{lc}
\hline Keterangan & Jumlah \\
\hline
\end{tabular}

Bagian HRD/atasan langsung dari mahasiswa kelas karyawan Prodi

80 orang

Akuntansi dan Prodi Akuntansi

Manajerial bekerja $\begin{array}{llll}\text { Bagian } & \text { HRD/atasan langsung } & \\ \text { mahasiswa } & \text { yang mengikuti FGD } & 8 \text { orang }\end{array}$

kurikulum akuntansi dan akuntansi manajerial

\begin{tabular}{|c|c|}
\hline Keterangan & Jumlah \\
\hline $\begin{array}{l}\text { Bagian HRD/atasan langsung } \\
\text { mahasiswa magang Politeknik Negeri } \\
\text { Batam khususnya Prodi Akuntansi dan } \\
\text { Prodi Akuntansi Manajerial }\end{array}$ & 90 orang \\
\hline Total & 178 orang \\
\hline
\end{tabular}

Berdasarkan tabel 1 Total data calon responden berjumlah 178 orang penyebaran.

\section{Teknik Pengumpulan dan pengolahan Data}

Penelitian ini menggunakan teknik survei dengan melakukan penyebaran kuesioner kepada 178 responden. Kuesioenr disebarkan secara online maupun offline.

Data yang diperoleh dari penyebaran kuesioner ditabulasi di dalam Microsoft excel, kemudian baru dilakukan pengolahan data penelitian menggunakan microsoft excel untuk mencari banyaknya frekuensi dan persentase sertifikasi yang digunakan diindustri.

\section{Teknik Analisis Data}

Teknik analisis data yang digunakan pada penelitian ini untuk menjawab rumusan masalah adalah menggunakan statistik deskriptif yang menjelaskan distribusi frekuensi dalam bentuk presentase dari sertifikasi yang digunakan di industri dan persepsi industri terkait dengan skill mahasiswa Akuntansi Politeknik Negeri Batam. Untuk menjawab pertanyaan penelitian tentang skala ranking penulis menggunakan rumus Henry Garret teknik ranking. Langkah pertama yang dilakukan adalah dengan mencari percent position dengan mengunakan rumus:

$$
\text { Percent position }=\frac{100(\mathrm{Rij}-0.5)}{\mathrm{Nj}}
$$

Setelah mendapatkan nilai percent position maka langkah selanjutnya adalah menentukan nilai garret value dengan melihat garret ranking conversion table. Kemudian mengalikan nilai ranking dari responden faktor pertama dengan garret value pertama, sampai semua skor garret selesai dikalikan. Kemudian hasil perhitungan skor garret tersebut dijumlahkan dan dibagi dengan hasil penjumlahan 
skor ranking oleh responden mengacu ada Dhanavandan (2016).

\section{Hasil dan Pembahasan}

\section{Hasil Pengumpulan Data}

Rincian hasil penyebaran kuesioner terdapat pada tabel 2 berikut:

Tabel 2

Rincian penyebaran kuesioner

\begin{tabular}{lc}
\hline \multicolumn{1}{c}{ Keterangan } & Jumlah \\
\hline Kuesioner yang disebarkan & 178 kuesioner \\
Kuesioner yang tidak kembali & 106 kuesioner \\
$\begin{array}{l}\text { Kuesioner yang dapat digunakan dan } \\
\text { diolah }\end{array}$ & 72 kuesioner \\
\hline
\end{tabular}

Berdasarakan tabel 2 terlihat bahwa dari 178 kuesioner yang disebarkan baik melalui google form maupun secara manual kuesioner yang dapat digunakan dan dapat diolah adalah sebanyak 72 kuesioner.

\section{Pembahasan}

Sertifikasi Kompetensi Dibutuhkan di Industri berkaitan dengan skill di Bidang Akuntansi

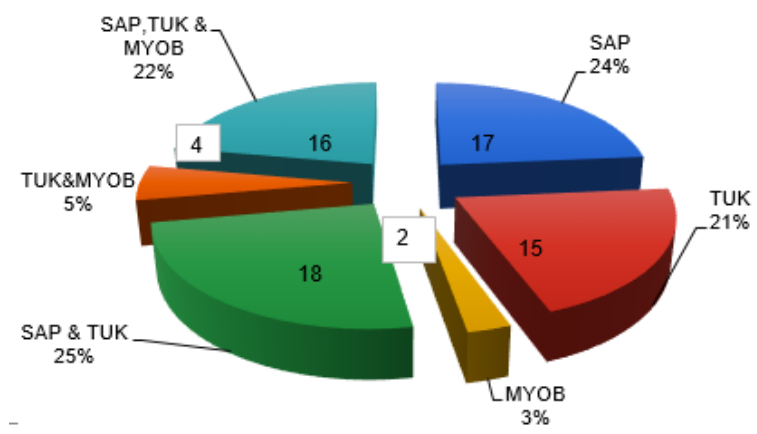

Gambar 1. Sertifikasi kompetensi yang dibutuhkan oleh industri

Dari 72 perusahaan yang menjadi responden terlihat bahwa 16 perusahaan menyatakan bahwa sertifikasi SAP, TUK dan MYOB dibutuhkan diindustri. 17 Perusahaan lagi menyatakan bahwa sertifikasi SAP dibutuhkan, 18 perusahaan menyatakan hanya SAP dan TUK. 15 perusahaan menyatakan hanya sertifikasi TUK. 4 perusahaan, menyatakan bahwa sertifikasi TUK dan MYOB yang dibutuhkan. dan 2 perusahaan menyatakan hanya MYOB sertifikasiyang dibutuhkan oleh industri.

Masukan Dari Industri Terkait Dengan Sertifikasi Kompetensi Yang Diikuti oleh Mahasiswa Akuntansi

Menurut pandangan industri terkait dengan sertifikasi kompetensi Mahasiswa Akuntansi yang perlu diikuti dan dibutuhkan diindustri secara garis besar terbagi menjadi beberapa kelompok yaitu:

1. Sertifikasi terkait dengan penggunaan software Akuntansi

2. Sertifikasi terkait dengan Microsoft excel (Macro \& Formula Excel) dan reporting analysis

3. Sertifikasi terkait dengan Pajak minimal lokal Brevet Pajak A dan B

4. Sertifikasi bahasa inggris TOEFL/TOEIC

5. Sertifikasi kompetensi mengetik sepuluh jari cepat dan ringkas

6. Sertifikasi Akuntansi Jasa Bidang Pendidikan (Apl. SIP BOS)

7. Sertifikasi CPAI oleh IAPI

8. Six sigma

Skill yang Sudah Dimiliki Oleh Mahasiswa Akuntansi yang Bekerja di Industri

Berdasarkan Grafik batang pada Gambar 2 terlihat bahwa skill yang sudah dimiliki mahasiswa Akuntansi Politeknik Negeri Batam agar dapat bersaing pada era industri 4.0 menurut survei industri adalah 56 responden industri menyatakan bahwa skill yang sudah dimiliki adalah pembelajaran yang aktif dan strategis, kemudian 50 responden menyatakan berpikir analitis dan inovatif, selanjutnya 46 respon menyatakan skill kemampuan analitis dan daya pikir kritis, 43 responden menyatakan skill kreativitas, originalitas dan inisiatif, 38 responden menyatakan skill kecerdasan emosional, 35 responden menyatakan kemampuan memecahkan masalah yang sulit dan skill logika penyelesaian masalah, reasoning dan penuh ide. 29 responden kemampuan analisis sistem dan evaluasi. 21 responden kepemimpinan dan kemampuan memberikan pengaruh kepada lingkungan sosial dan 14 responden kemampuan programming dan teknologi desain. Penjelasan detail dapat dilihat pada gambar berikut ini. 


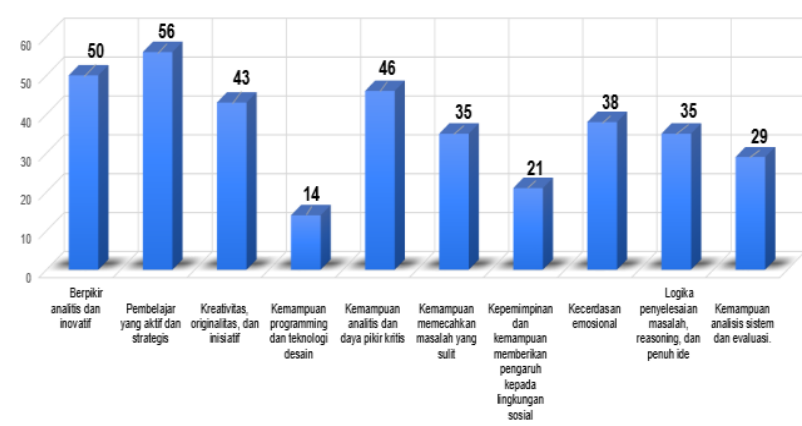

Gambar 2. Skill yang sudah dimiliki oleh mahasiswa Akuntansi agar dapat bersaing pada era industri 4.0

Skill yang paling dibutuhkan oleh lulusan mahasiswa akuntansi, dalam menghadapi Era Industri 4.0 menurut industri

Tabel berikut ini menunjukkan hasil perhitungan percent position dan Garret value:

Tabel 3

Nilai Percent position dan Garret Value

\begin{tabular}{cccc}
\hline Rank & $100($ RIJ-0,5) & $\begin{array}{c}\text { percent } \\
\text { position }\end{array}$ & $\begin{array}{c}\text { Garret } \\
\text { value }\end{array}$ \\
\hline F1 & $100 *(1-0,5) / 10$ & 5 & 82 \\
F2 & $100 *(2-0,5) / 10$ & 15 & 70 \\
F3 & $100 *(3-0,5) / 10$ & 25 & 63 \\
F4 & $100 *(4-0,5) / 10$ & 35 & 58 \\
F5 & $100 *(5-0,5) / 10$ & 45 & 52 \\
F6 & $100 *(6-0,5) / 10$ & 55 & 48 \\
F7 & $100 *(7-0,5) / 10$ & 65 & 42 \\
F8 & $100 *(8-0,5) / 10$ & 75 & 36 \\
F9 & $100 *(9-0,5) / 10$ & 85 & 29 \\
F10 & $100 *(10-0,5) / 10$ & 95 & 18 \\
\hline
\end{tabular}

Berikut ini adalah data nilai perangkingan dari responden:
Tabel 4

Hasil perankingan dari responden

\begin{tabular}{rrrrrrrrrrr}
\hline Faktor & $\mathbf{1}$ & $\mathbf{2}$ & $\mathbf{3}$ & $\mathbf{4}$ & $\mathbf{5}$ & $\mathbf{6}$ & $\mathbf{7}$ & $\mathbf{8}$ & $\mathbf{9}$ & $\mathbf{1 0}$ \\
\hline 1 & 16 & 5 & 7 & 1 & 2 & 3 & 0 & 9 & 3 & 5 \\
2 & 7 & 12 & 11 & 2 & 4 & 0 & 6 & 1 & 5 & 0 \\
3 & 4 & 8 & 12 & 2 & 7 & 1 & 1 & 4 & 4 & 2 \\
4 & 4 & 3 & 1 & 11 & 4 & 6 & 4 & 3 & 6 & 2 \\
5 & 3 & 2 & 2 & 5 & 9 & 9 & 5 & 3 & 6 & 7 \\
6 & 3 & 1 & 5 & 7 & 5 & 12 & 3 & 5 & 4 & 7 \\
7 & 2 & 5 & 6 & 11 & 9 & 9 & 19 & 7 & 6 & 6 \\
8 & 18 & 18 & 11 & 13 & 18 & 17 & 13 & 25 & 14 & 15 \\
9 & 11 & 10 & 13 & 8 & 9 & 11 & 14 & 10 & 20 & 14 \\
10 & 4 & 8 & 4 & 11 & 4 & 4 & 7 & 5 & 4 & 14 \\
\hline & & & & & & & & & &
\end{tabular}

Langkah selanjutnya adalah melakukan perkalian nilai Garret value dengan nilai hasil perangkingan oleh responden. Hasil perhitungan dapat terlihat pada table 5:

Tabel 5

Hasil perkalian antara Garret Value dengan nilai hasil perangkingan responden

\begin{tabular}{cccccccccccc}
\hline Faktor & $\begin{array}{c}\text { 1st } \\
{ }^{*} 82\end{array}$ & $\begin{array}{c}\text { 2nd } \\
{ }^{*} 70\end{array}$ & $\begin{array}{c}\text { 3rd } \\
{ }^{*} 63\end{array}$ & $\begin{array}{c}\text { 4th } \\
{ }^{*} 58\end{array}$ & $\begin{array}{c}\text { 5th } \\
{ }^{*} 52\end{array}$ & $\begin{array}{c}\text { 6th } \\
{ }^{*} 48\end{array}$ & $\begin{array}{r}\text { 7th } \\
{ }^{*} 42\end{array}$ & $\begin{array}{c}\text { 8th } \\
{ }^{*} 36\end{array}$ & $\begin{array}{c}\text { 9th } \\
{ }^{*} 29\end{array}$ & $\begin{array}{c}\text { 10th } \\
{ }^{*} 18\end{array}$ & TOTAL \\
\hline 1 & 1312 & 350 & 441 & 58 & 104 & 144 & 0 & 324 & 87 & 90 & 2910 \\
2 & 574 & 840 & 693 & 116 & 208 & 0 & 252 & 36 & 145 & 0 & 2864 \\
3 & 328 & 560 & 756 & 116 & 364 & 48 & 42 & 144 & 116 & 36 & 2510 \\
4 & 328 & 210 & 63 & 638 & 208 & 288 & 168 & 108 & 174 & 36 & 2221 \\
5 & 246 & 140 & 126 & 290 & 468 & 432 & 210 & 108 & 174 & 126 & 2320 \\
6 & 246 & 70 & 315 & 406 & 260 & 576 & 126 & 180 & 116 & 126 & 2421 \\
7 & 164 & 350 & 378 & 638 & 468 & 432 & 798 & 252 & 174 & 108 & 3762 \\
8 & 1476 & 1260 & 693 & 754 & 936 & 816 & 546 & 900 & 406 & 270 & 8057 \\
9 & 902 & 700 & 819 & 464 & 468 & 528 & 588 & 360 & 580 & 252 & 5661 \\
10 & 328 & 560 & 252 & 638 & 208 & 192 & 294 & 180 & 116 & 252 & 3020 \\
\hline
\end{tabular}

Setelah didapat hasil perkalian, maka hasil perkalian tersebut selanjutnya diranking. Ranking skill yang dibutuhkan agar dapat bersaing terlihat pada tabel 6: 
Tabel 6

Hasil Ranking Skill yang dibutuhkan di industri untuk dapat bersaing pad Era industri 4.0

\begin{tabular}{ccccc}
\hline FAKTOR & $\begin{array}{c}\text { TOTAL NILAI } \\
\text { RANKING DARI } \\
\text { RESPONDEN }\end{array}$ & $\begin{array}{c}\text { TOTAL } \\
\text { GARRET } \\
\text { VALUE }\end{array}$ & $\%$ & RANK \\
\hline 1 & 51 & 2910 & 57,06 & 2 \\
2 & 48 & 2864 & 59,67 & 1 \\
3 & 45 & 2510 & 55,78 & 3 \\
4 & 44 & 2221 & 50,48 & 4 \\
5 & 51 & 2320 & 45,49 & 10 \\
6 & 52 & 2421 & 46,56 & 8 \\
7 & 80 & 3762 & 47,03 & 7 \\
8 & 162 & 8057 & 49,73 & 5 \\
9 & 120 & 5661 & 47,18 & 6 \\
10 & 65 & 3020 & 46,46 & 9 \\
\hline
\end{tabular}

Setelah di ranking kemudian dijabarkan skill yang dibutuhkan kedalam grafik berikut ini:

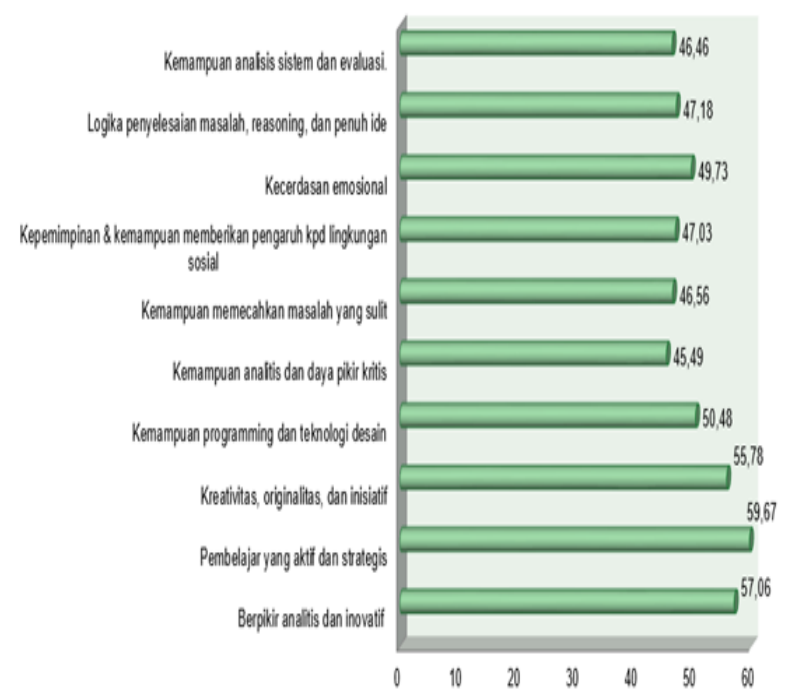

Gambar 3. Hasil perangkingan Skill dengan menggunakan Metode Garret

Berdasarkan gambar 4 terlihat bahwa Skill yang paling dibutuhkan oleh lulusan mahasiswa akuntansi, dalam menghadapi Era Industri 4.0 hasil perangkingan menurut industri adalah skill pembelajaran yang aktif dan strategis sebesar $59,67 \%$, kemudian rangking ke dua adalah skill berpikir analitis dan inovatif sebesar 57,06\%, selanjutnya $55,78 \%$ Kreativitas, originalitas, dan inisiatif, ranking ke empat adalah skill Kemampuan programming dan teknologi desain sebesar 50,48\%. Kecerdasan emosional sebesar 49,73\% menempati ranking ke lima. Kemudian selanjutnya ranking ke enam adalah logika penyelesaian masalah, reasoning, dan penuh ide sebesar 47,18\%. Rangking ke tujuh ditempati oleh skill Kepemimpinan dan kemampuan memberikan pengaruh kepada lingkungan sosial sebesar 47,03\%. Kemampuan memecahkan masalah yang sulit sebesar $46,56 \%$ menempati urutan ke delapan. Disusul skill kemampuan analisis sistem dan evaluasi sebesar $46,46 \%$ dan $45,49 \%$ skill kemampuan analitis dan daya pikir krit

\section{Kesimpulan}

Penelitian ini bertujuan untuk mengetahui apakah sertifikasi kompetensi yang selama ini diperoleh mahasiswa di jenjang perkuliahan akan digunakan di dunia kerja/industri. Penelitian ini juga ingin mengetahui persepsi industri terkait dengan skill mahasiswa Akuntansi Politeknik Negeri Batam yang telah bekerja di industri, dan mengetahui skill yang diperlukan lulusan mahasiswa Akuntansi agar dapat bersaing di Era Industri 4.0. Hasi penelitian ini menunjukkan bahwa:

a. Sertifikasi kompetensi yang selama ini diadakan oleh jurusan manajemen bisnis ternyata memang dibutuhkan di dunia kerja dengan hali ini terbukti dari 72 responden terlihat bahwa 16 responden yang merupakan perwakilan perusahaan menyatakan bahwa sertifikasi SAP, TUK dan MYOB dibutuhkan diindustri. 17 Perusahaan lagi menyatakan bahwa sertifikasi SAP dibutuhkan, 18 perusahaan menyatakan hanya SAP dan TUK. 15 perusahaan menyatakan hanya sertifikasi TUK. 4 perusahaan, menyatakan bahwa sertifikasi TUK dan MYOB yang dibutuhkan. dan 2 perusahaan menyatakan hanya MYOB sertifikasiyang dibutuhkan oleh industri. Masukan industri terkait sertifikasi yang juga dibutuhkan di dunia kerja adalah Sertifikasi terkait dengan penggunaan software Akuntansi, Sertifikasi terkait dengan Microsoft excel (Macro \& Formula Excel) dan reporting analysis, Sertifikasi terkait dengan Pajak minimal lokal Brevet Pajak A dan B, Sertifikasi bahasa inggris TOEFL/TOEIC, Sertifikasi kompetensi mengetik sepuluh jari cepat dan ringkas, Sertifikasi 
Akuntansi Jasa Bidang Pendidikan (Apl. SIP BOS), Sertifikasi CPAI oleh IAPI, Six sigma

b. Persepsi industri terkait dengan skill mahasiswa Akuntansi Politeknik Negeri Batam yang telah bekerja di industri adalah 56 responden industri menyatakan bahwa skill yang sudah dimiliki adalah pembelajaran yang aktif dan strategis, kemudian 50 responden menyatakan berpikir analitis dan inovatif, selanjutnya 46 respon menyatakan skill kemampuan analitis dan daya pikir kritis, 43 responden menyatakan skill kreativitas, originalitas dan inisiatif, 38 responden menyatakan skill kecerdasan emosional, 35 responden menyatakan kemampuan memecahkan masalah yang sulit dan skill logika penyelesaian masalah, reasoning dan penuh ide. 29 responden kemampuan analisis sistem dan evaluasi. 21 responden kepemimpinan dan kemampuan memberikan pengaruh kepada lingkungan sosial dan 14 responden kemampuan programming dan teknologi desain.

c. skill yang diperlukan lulusan mahasiswa Akuntansi agar dapat bersaing di Era Industri 4.0 hasil perangkingan industri rangking pertama adalah skill pembelajaran yang aktif dan strategis sebesar 59,67\%, kemudian rangking ke dua adalah skill berpikir analitis dan inovatif sebesar $57,06 \%$, selanjutnya $55,78 \% \quad$ Kreativitas, originalitas, dan inisiatif, ranking ke empat adalah skill Kemampuan programming dan teknologi desain sebesar 50,48\%. Kecerdasan emosional sebesar 49,73\% menempati ranking ke lima. Kemudian selanjutnya ranking ke enam adalah logika penyelesaian masalah, reasoning, dan penuh ide sebesar 47,18\%. Rangking ke tujuh ditempati oleh skill Kepemimpinan dan kemampuan memberikan pengaruh kepada lingkungan sosial sebesar 47,03\%. Kemampuan memecahkan masalah yang sulit sebesar 46,56\% menempati urutan ke delapan. Disusul skill kemampuan analisis sistem dan evaluasi sebesar $46,46 \%$ dan $45,49 \%$ skill kemampuan analitis dan daya pikir kritis

\section{Daftar Pustaka}

Dhanavandan, S. (2016). Appllication of Garret Ranking
Technique: Practical Approach. International Journal of Library and Information Studies. Vol. 6 Issue: 2, pp. 135-140.

Fauzia. (2018). Di Tahun 2022, Skill Apa Saja yang Paling Dibutuhkan untuk Bekerja?. Diakses 3 Desember 2018. Dapat diakses

https://ekonomi.kompas.com/read/2018/11/09/101201726/ditahun-2022-skill-apa-saja-yang-paling-dibutuhkan-untuk-bekerja.

Kagermann, H., Wahlster, W., \& Helbig, J. (2013). Recommendations for implementing the strategic initiative industrie 4.0. Final Report of Industrie 4.0 Working Group.

Kazancoglu, Y \& Ozen, Y D O. (2017). Analyzing Workforce 4.0 in the Fourth Industrial Revolution and proposing a road map from operations management perspective with fuzzy DEMATEL. Journal of Enterprise Information Management. Vol. 31 Issue: 6, pp.891-907.

Nugroho. (2018). Sertifikasi kompetensi tingkatkan kredibilitas profesi lulusan fti ubsi. Diakses 5 Maret 2019. dapat diakses: http://wartakota.tribunnews.com/2018/11/15/sertifikasi-

kompetensi-tingkatkan-kredibilitas-profesi-lulusan-fti-ubsi.

Oztomel, E \& Gursev, S. (2018). Literature Review of Industry 4.0 and Related Technologies. Journal of Intelligent Manufacturing.

Peraturan Pemerintah Nomor 4 tahun 2014 tentang penyelenggaraan pendidikan tinggi dan pengelolaan perguruan tinggi

Majid, S., Eapen, C.M., Aung, E.M., \& Oo, K. T. (2019). The Importance of Soft Skills for Employability and Career Development: Students and Employers' Perspectives. The IUP Journal of Soft Skill. Vol. 13 Issue: 4

SINDOnews. (2018). Ijazah Sarjana Saja Tidak Cukup, Harus Miliki Sertifikasi Kompetensi. Diakses 6 Januari 2019. Dapat diakses: https://nasional.sindonews.com/read/1364544/144/ijazahsarjana-saja-tidak-cukup-harus-miliki-sertifikasi-kompetensi1545318343

Tim VIVA. (2018). Hadapi Revolusi Industri 4.0, Kompetensi SDM Jadi Kunci. Diakses 10 Februari 2019. Dapat diakses: https://www.viva.co.id/berita/bisnis/1030796-hadapi-revolusiindustri-4-0-kompetensi-sdm-jadi-kunci.

Villiers, R. D. (2010). The Incorporation of Soft Skills into Accounting Curricula: Preparing Accounting Graduates for Their Unpredictable Futures. Meditari Accountancy Research. Vol. 18 Issue: 2, pp. 1-22

Wijayanto. (2019). Sambut Revolusi Industri 4.0, Gubernur Dorong Pendidikan Vokasi. Diakses 2 Februari 2019. Dapat diakses:https://radarsurabaya.jawapos.com/read/2019/01/30/11680 9/sambut-revolusi-industri-40-gubernur-dorong-pendidikanvokasi.

World Economic Forum Centre For The New Economy and Society. (2018). The Future of Jobs Report 2018. Retrieved from http://reports.weforum.org/future-of-jobs 2018/ 